\title{
Polymorphisms Associated With Low Bone Mass and High Risk of Atraumatic Fracture
}

\author{
I. ZOFKOVA ${ }^{1}$, P. NEMCIKOVA ${ }^{2}$, M. KUKLIK ${ }^{1}$ \\ ${ }^{1}$ Institute of Endocrinology, Prague, Czech Republic, ${ }^{2}$ Department of Nuclear Medicine, České \\ Budějovice, Czech Republic
}

Received November 26, 2014

Accepted February 5, 2015

On-line March 24, 2015

\section{Summary}

Osteoporosis is a serious disease characterized by high morbidity and mortality due to atraumatic fractures. In the pathogenesis of osteoporosis, except environment and internal factors, such as hormonal imbalance and genetic background, are also in play. In this study candidate genes for osteoporosis were classified according to metabolic or hormonal pathways, which regulate bone mineral density and bone quality (estrogen, RANKL/RANK/OPG axis, mevalonate, the canonical circuit and genes regulating the vitamin $D$ system). COL1A1 and/or COL1A2 genes, which encode formation of the procollagen 1 molecule, were also studied. Mutations in these genes are well-known causes of the inborn disease 'osteogenesis imperfecta'. In addition to this, polymorphisms in COL1A1 and/or COL1A2 have been found to be associated with parameters of bone quality in adult subjects. The authors discuss the perspectives for the practical utilization of pharmacogenetics (identification of single candidate genes using PCR) and pharmacogenomics (using genome wide association studies (GWAS) to choose optimal treatment for osteoporosis). Potential predictors of antiresorptive therapy efficacy include the following well established genes: ER, FDPS, Cyp19A1, VDR, Col1A1, and Col1A2, as well as the gene for the canonical (Wnt) pathway. Unfortunately, the positive outcomes seen in most association studies have not been confirmed by other researchers. The controversial results could be explained by the use of different methodological approaches in individual studies (different sample size, homogeneity of investigated groups, ethnic differences, or linkage disequilibrium between genes). The key pitfall of association studies is the low variability (7-10\%) of bone phenotypes associated with the investigated genes. Nevertheless, the identification of new genes
\end{abstract}

and the verification of their association with bone density and/or quality (using both PCR and GWAS), remain a great challenge in the optimal prevention and treatment of osteoporosis.

\section{Key words}

Bone mineral density • Osteoporosis • Osteogenesis imperfecta • Genome-wide association studies - Bone remodeling • Osteoporosis polymorphisms • Estrogen • Vitamin D

\section{Corresponding author}

I. Zofkova, Institute of Endocrinology, Narodni 8, 11694 Prague 1, Czech Republic. E-mail: izofkova@upcmail.cz

\section{Introduction}

Osteoporosis is a common serious disease with high morbidity and mortality. The early identification of at-risk individuals during the premorbid stage of the disease is a paramount precondition for the effective prevention of osteoporosis. Known causes of low bone density include hypoestrinism, nutritional deficiency (low intake of calcium, vitamins D and K), limited physical activity, „frailty“ syndrome, nicotinism or excessive alcohol consumption. Part of the upward trend in the number of cases of osteoporosis is linked the rising incidence of autoimmune, rheumatic, and other diseases, the increasing number of patients with glucocorticoidsinduced osteoporosis, and other immunosuppressive pharmaceuticals, and the use of anti-epileptics and anticoagulant agents. Results from studies in affected families have confirmed that osteoporosis is a hereditary 
disease. It is known that the daughters or granddaughters of women with low bone mineral density develop osteoporosis more often than the daughters or granddaughters of women with normal bone density (Obermayer-Pietsch 2006).

Growing evidence indicates that osteoporosis involves multifactorial inheritance through a combination of genetic and environmental factors.

The degree of bone phenotype heritability (loss of bone density, biochemical markers of bone remodeling, structure and size of bones, and number of fractures) was measured in twin studies using the formula $\mathrm{H}^{2}=2 \mathrm{x}(\mathrm{rMz}-\mathrm{rDz})$, where $\mathrm{rMz}$ and $\mathrm{rDz}$ are correlations found in monozygotic and dizygotic twins. $\mathrm{H}^{2}$ expresses the degree of genetically determined variations in bone phenotype (Bathum et al. 2004). It has been reported that the heritability of bone density is 60 to $80 \%$, which means that $60-80 \%$ of bone mineral variation can be explained by genetic background. The heritability of bone density may depend on bone location within the skeleton. It was found that $\mathrm{H}^{2}$ in the lumbar spine is 0.89 , while the $\mathrm{H}^{2}$ of the femoral neck (where mechanical load is greater) is 0.77 (Ongphiphadanakul 2007). Twin studies have consistently shown that genetic factors account for approximately $80 \%$ of bone mineral density variability at all ages, indicating that genes are important in determining both peak bone mass and the rate of bone loss in later life (Young 2002).

Initially, chromosomal loci were identified, that determine bone mineral density (BMD) and its fragility, bone geometry and bone remodeling. Later, the allelic variants of a single nucleotide polymorphisms (SNPs), which controlled bone phenotypes, were identified (polymorphisms in the ER $\alpha$ gene located at chromosome $6 \mathrm{q} 25.1$, the vitamin D receptor located at 12q12-q14, the calcitonin receptor at 7q21.3 CALCR, or polymorphisms regulating the expression of TGF $\beta 1$, BMP-4, IGF-1, CYP17, the interleukin 1 receptor antagonist, interleukin 6 and the parathyroid hormone receptor). SNPs are identified using PCR, or a two-dimensional analysis of a wide range of genes using genome-wide association studies (GWAS) (Guo et al. 2010).

The majority of the genes associated with osteoporosis are, at present, fairly well established. However, to date no gene has been definitively identified as a major gene.

Despite extensive research over the past two decades, little progress has been made in the identification of the genes that regulate bone remodeling, bone density, and fracture risk. Even GWAS datasets suffer from a number of limitations. An alternative approach was used by Farber (2013), in which he indentified novel interactions for genes having a known role in the regulation of bone mass. Array technologies are now capable of analyzing thousands of polymorphisms distributed throughout the genome. To date approximately 20 GWAS with osteoporosis phenotypes have been carried out. For example, GWAS identified SNPs in more than 2000 women that were associated with bone mineral density (SNPs rs4355801 located on chromosome 8 , close to the osteoprotegerin gene, and rs3736228 polymorphism in the LRP5 gene on chromosome 11, associated with osteoporosis and/or atraumatic fractures (Richards et al. 2008).

Recently, a large a genome-wide association study performed on more than 5000 individuals of European origin found that a deletion located on chromosome $6 \mathrm{p} 25.1$ might predispose carriers to a higher risk of fracture (Oei et al. 2014). However, this association has not been observed in other geographically defined populations.

Our review offers overview of genes associated with osteoporosis and linked to bone-regulating hormonal circuits. Furthermore, it discusses possible roles of pharmacogenetics/pharmacogenomics with regard to response modulation associated with anti-osteoporotic pharmaceuticals.

\section{Survey of fundamental genes for osteoporosis (Tables 1-3)}

\section{Genes encoding the estrogen circuit}

Bone remodeling is markedly regulated by ovarian estrogens, which inhibit bone resorption directly through the ER1 $(\mathrm{ER} \alpha)$ and ER2 $(\mathrm{ER} \beta)$ receptors in bone, or via the inhibition of osteoresorptive cytokines (interleukin-1, TNF $\alpha$ ). The gene responsible for bone phenotype regulation is also the gene for the estrogen receptor (Xba1 and PvuII polymorphisms). A metaanalysis of 22 studies involving 5,000 women showed that the XX genotype of the XbaI polymorphism was associated with a high value of BMD in both the spine and the femoral neck, compared to carriers of the $\mathrm{x}$ allele. Within the Finnish population, the incidence of fractures was associated with the PvuII polymorphism (carriers of the $\mathrm{P}$ allele have a lower incidence compared with carriers of the $\mathrm{p}$ allele). Another meta-analysis of 
European institution studies involving 19,000 probands found an association between $E R \alpha$ and the risk of fractures, which did not always correlate with BMD (reviewed by Marini and Brandi 2013, Riancho and Hernández 2012). ER $\alpha$ studies in postmenopausal Italian women indicate that intragenic polymorphisms make a small, but statistically significant contribution to the heritability of bone mineral density (Young 2002). In the Caucasian population, an association between BMD and one SNP in the gene for ER $\beta$ was found in women, while this same phenotype was associated with three SNPs in the same gene in men (Ichikawa et al. 2005). This study shows a certain sexual differentiation in the relation between gene and bone phenotype.

Table 1. Polymorphisms of candidate genes for bone mineral density (Marini and Brandi 2013, modified).

\begin{tabular}{llll}
\hline Candidate gene & Polymorphism & SNP & Localization \\
\hline VDR & FokI & rs2228570 & Exon 2 \\
VDR & BsmI & rs1544410 & Intron 8 \\
VDR & TaqI & rs731236 & Exon 9 \\
ER $\alpha$ & PvuII & rs2344693 & Intron 1 \\
ER $\alpha$ & XbaI & rs9340799 & Intron 1 \\
ER $\alpha$ & & rs3798575 & Intron 6 \\
COL1A1 & Sp1 & rs1800012 & Intron 1 \\
TNFRSF11B & OPG(A163G) & rs3102735 & Promoter region 5'UTR \\
TNFRSF11B & OPG (T245G) & rs134069 & Promoter region 5'UTR \\
NFRSF & OPG (T950C) & rs2073617 & Promoter region 5'UTR \\
FDPS & & rs11264359 & 5'UTR \\
GGPS1 & & rs3840452 & Promoter region 5'UTR \\
LRP5 & C3893T & & Exon 18 \\
\hline
\end{tabular}

The regulatory effect of estrogen on the skeleton probably has a wider sphere of influence. Genes for estrogen not only modulate bone density directly, but also through the precursors of sex steroids, or through binding proteins for sex steroids (SHBG). In a pilot study, the Xbal polymorphism in ER $\alpha$ was associated with androstenedione levels in postmenopausal women (Zofkova et al. 2002). The relationship to BMD has also been observed in the polymorphism of the SHBG gene (Riancho et al. 2008). Furthermore, CYP19A1 (located on the 15th chromosome) probably modulates BMD via aromatization of androgens to estrogen (Simpson 2000).

\section{RANK-RANKL-OPG (circuit regulating bone remodeling)}

RANKL is a protein in the tumor necrosis factor (TNF) family; it is produced by osteoblasts and encoded by the TNFRSF11 (TNFRSF11A) gene. RANKL is the target molecule of osteoresorptive cytokines, thus it is not surprising that there is a relationship between bone parameters and genes encoding cytokine production.
Czerny et al. (2010) found an association between the $174 \mathrm{G} / \mathrm{C}$ polymorphism in the gene for IL-6 and bone density, in a group of osteoporotic (but not healthy) postmenopausal women. Therefore, the regulatory effect of the IL-6 gene on BMD clearly depends on bone remodeling activity.

The candidate gene for osteoprotegerin (OPG) (the false soluble RANKL receptor, which blocks the binding of RANKL to RANK) is TNFRSF11B. In postmenopausal Chinese women a relationship between the $\mathrm{G}$ allele in the gene for OPG (the A163G and T245G polymorphism) and the risk of osteoporosis was found (Wang et al. 2009). Similarly, a relationship has been observed between the polymorphisms $1181 \mathrm{G}>\mathrm{C}$ and $245 \mathrm{~T}>\mathrm{G}$ in the TNFRSF11B gene and BMD within the Caucasian population (Mencej-Bedrač et al. 2011). However, this association was not confirmed by a modified study in a large group of Australian women (Ueland et al. 2007). The differences between these studies could be related to different frequencies of allelic combinations in different populations. 
Table 2. Selection of genes associated with bone density of the femoral neck or spine identified using GWAS method (Riancho and Hernández 2012, modified).

\begin{tabular}{|c|c|c|}
\hline Candidate gene & Locus & SNP \\
\hline \multicolumn{3}{|l|}{ Wnt genes circuit } \\
\hline LRP5 & $11 \mathrm{q} 13.2$ & rs3736228 \\
\hline SOST & $17 \mathrm{q} 21.31$ & rs4792909 \\
\hline WNT16/FAM3C & $7 \mathrm{q} 31.31$ & rs3801387 \\
\hline WNT4 & $1 \mathrm{p} 36.12$ & rs7521902 \\
\hline AXIN1 & $16 \mathrm{p} 13.3$ & rs9921222 \\
\hline \multicolumn{3}{|c|}{ Genes for RANK-RANKL-OPG } \\
\hline OPG(TNFRSF11B) & $8 \mathrm{q} 24.12$ & rs206237 \\
\hline RANK(TNFRSF11A) & $18 q 2133$ & rs884205 \\
\hline RANKL(TNFRSF11) & $13 q 14$ & rs9533090 \\
\hline \multicolumn{3}{|c|}{$\begin{array}{l}\text { Gene encoding sclerostin levels in the blood } \\
\text { (found in black Caribbean population) }\end{array}$} \\
\hline SOST & $17 \mathrm{q} 11.2$ & $\begin{array}{l}\text { rs851056 } \\
\text { rs41455049 } \\
\text { rs9909172 }\end{array}$ \\
\hline \multicolumn{3}{|c|}{ Genes for endochondral ossification } \\
\hline CDKA1/SOX4 & $6 \mathrm{p} 22.3$ & rs9466056 \\
\hline SOX6 & $11 \mathrm{p} 15.2$ & rs7108738 \\
\hline SP7 & $12 q 13.13$ & rs2016266 \\
\hline SUPT3/RUNX2 & $6 \mathrm{p} 21.1$ & rs11755164 \\
\hline
\end{tabular}

Genes associated with the Wnt (canonical) circuit (Table 2)

Wnt signaling modulates cell differentiation through the non-canonical pathway (via calcium or cAMP signals) or through the canonical pathway, in which $\beta$-catenin plays a central role. The differentiation of osteoblasts is mostly under the control of canonical signaling. Wnt ( $\beta$-catenin) binds to LRP receptor proteins (a low density lipoprotein-related protein) and FZDs (Frizzled receptors). Following the transfer of LRP and FZD into the nucleus of the pre-osteoblast and binding to transcription factor TCFS, proliferation and differentiation of this cell is induced (Whyte et al. 2004, Glass et al. 2005). Wnt inhibitors of canonical pathways, such as SFRP3 (encoded by the FRZB gene), DKK1-4 and sclerostin (encoded by the SOST gene) suppress bone formation. On the other hand, it was found that antibodies against one of these inhibitors (e.g. anti-sclerostin antibodies) can increase BMD values in rats with hypoestrinism (Li et al. 2009).
The canonical pathway is controlled by the LRP5 gene (Glass et al. 2005). The inactivation mutation in LRP5 manifests as juvenile osteoporosis in humans, on the contrary, activating mutation as osteopetrosis. A multicenter study of 37,534 participants from Europe and North America showed, that the V667M (in the exon 9) and A1330V (in the exon 18) polymorphisms of this gene were associated with a low BMD value and an increased incidence of fractures (van Meurs et al. 2008).

\section{Gene for type I collagen}

The majority of osteogenesis imperfecta (OI) cases are caused by mutations in one of the two genes, COL1A1 and COL1A2 encoding the two chains that trimerize to form the procollagen 1 molecule (Valadares et al. 2014). Alterations in gene expression and microRNAs (miRNAs) are responsible for the regulation of cell fate determination and may be involved in the OI phenotype. Uitterlinden et al. (1998) showed, that a combination of the alleles $\mathrm{S}$ and $\mathrm{s}$ in the Sp1 COL1A1 polymorphism was associated with a risk of fracture in the Caucasian population. The carriers of this combination had a 2.7 times higher risk of fracture than the carriers of the SS or ss genotypes. The relationship between COL1A1 and the risk of fractures was later confirmed by other authors (Ralston et al. 2006 - GENOMOS study, Jin et al. 2009). The genes that have been found to be associated with both fracture risk and low BMD values are summarized in Table 3 (Mitchell and Streeten 2013).

Mutations in the COL1A1 and COL1A2 genes cause special forms of inherited osteoporosis, such as osteogenesis imperfecta (OI). OI is a brittle bone disease that is inherited in an autosomal dominant manner, is often multisystemic, and affects whole families (Primorac et al. 2014). Most nonsense or missense mutations, insertions and partial gene deletions lead to a reduction in the amount of type I collagen (haplo-insufficiency). Mild cases of OI can result in a diagnosis of osteoporosis in adulthood or at an advanced age (O'Sullivan et al. 2014). Recently, the genetic heterogeneity in OI has been confirmed through molecular genetics studies. At present, 17 genetic causes of OI have been identified (Van Dijk and Sillence 2014). The amino-acid glycine is the most obvious in the linear collagen sequence and correlate with the observed frequency of targeted mutations which were found. Nevertheless, the COL1A1 gene (located on the 17q21.31-q22 chromosome) also predicts bone quality in osteoporotic subjects without OI (Table 1, modified according to Marini and Brandi 2013, Brown et al. 2002). 
Table 3. Selected candidate genes associated with bone density and with osteoporotic fractures (Mitchell and Streeten 2013, modified).

\begin{tabular}{llll}
\hline Candidate gene & Locus & SNP & Encoding \\
\hline $\begin{array}{l}\text { Wnt circuit } \\
\text { CTNNB1 }\end{array}$ & $3 \mathrm{p} 22.1$ & & \\
LRP5 & $11 \mathrm{q} 13.2$ & rs430727 & $\beta$-catenin \\
MBL2/DKK1 & $10 \mathrm{q} 21.1$ & rs3736228 & lipoprotein receptor related peptide 5 \\
SOST & $17 \mathrm{q} 21.31$ & rs47373004 & \\
WNT16/FAM3C & $7 \mathrm{q} 3131$ & rs3801367 & sclerostin \\
WNT4 & $1 \mathrm{p} 36.12$ & rs7521902 & Wingless proteins-type MMTV4 \\
RANK-RANKL-OPG system & & & \\
TNFRSF11 & $13 \mathrm{q} 14$ & rs9333090 & receptor TNF 11 (RANKL) \\
TNFRSF11A & $18 \mathrm{q} 21.33$ & rs884205 & receptor TNF 11a (RANKL) \\
TNFRSF11B & $8 \mathrm{q} 2412$ & rs2062377 & receptor TNF 11b (OPG) \\
Gene for endochondral ossification & & & \\
MEPE/SPP1/IBSP & $4 \mathrm{q} 21.1$ & rs6532023 & \\
\hline
\end{tabular}

\section{Genes for vitamin D and calcitonin}

The metabolite of vitamin $\mathrm{D}\left(1,25(\mathrm{OH})_{2} \mathrm{D}_{3}\right)$ plays a key role in the regulation of bone metabolism. It activates specific receptors (VDR) on osteoblasts and stimulates bone formation. However, in high in vitro concentrations, it activates osteoclastic resorption. $1,25(\mathrm{OH})_{2} \mathrm{D}_{3}$ via VDR also regulates calcium homeostasis in vivo outside of the bone by reducing calcium and phosphorus loss in the kidneys, while stimulating their absorption in the intestines, thereby ensuring adequate bone matrix mineralization (reviewed by Rincho and Hernández 2012).

The gene for VDR was the first candidate gene, in which an association with bone mineral density was discovered by Morrison et al. (1994). The effect of the VDR genotype (the TaqI, BsmI and ApaI polymorphisms) on BMD has been found strongest in premenopausal women and decreases with age (Riggs et al. 1995). Later, however, only isolated studies found an association between VDR and BMD values (Masi et al. 2002), while other studies (including those using the GWAS method) had negative results. Instead, genes encoding the expression of protein-binding vitamin $\mathrm{D}$ (VDBP) and circulating 25(OH)D (CYP2R1) were identified, which predicted the risk of osteoporosis (reviewed by Riancho and Hernández 2012).

A study of an intragenic polymorphism in VDR led to the suggestion that this gene, mutations in which cause vitamin D-dependent rickets type II, could account for as much as $75 \%$ of the heritability of bone mineral density (Young 2002); although subsequent similar studies failed to confirm this observation.

Bone tissue is the primary target of calcitonin. An association between the calcitonin receptor (CTR) and bone mass has been found in several studies. In about 700 peri- and post-menopausal women, a relationship between CTR genotype (a combination of CC alleles) and bone mass was observed. However, binding was stronger in a sample of younger women (Braga et al. 2000). The relationship of CTR (the C1377T polymorphism) to BMD was observed in pilot studies of postmenopausal women (Masi et al. 2002, Zofkova et al. 2003a), however, other studies have not produced a consensus. Charopoulos et al. (2008) failed to document such an association in young Greek men. Therefore, the effect of genes on bone mass appears to not only depend on age, but gender and ethnicity, as well. The final answer should come when larger homogeneous samples are analyzed using the GWAS method.

Additional genes with a potential effect on the bone metabolism

An insufficiency in the lactase enzyme, which splits lactose in the intestine, leads to a gastrointestinal intolerance of dairy products, as well as secondary calcium deficiency and osteopenia (osteoporosis). Therefore, the gene coding for the synthesis of lactase may have predictive value for bone mass quality (Obermayer-Pietsch 2006). However, relevant studies demonstrating the relationship of this gene to bone parameters are still lacking. 
The gene for methyl tetrahydrofolate reductase (MTHFR) is responsible for the high levels of homocysteine, usually associated with some degenerative diseases (e.g. atherosclerosis). Interestingly, MTHFR also predicts the risk of osteoporotic fractures. In a senior population of twins, the association between this gene's C677T polymorphism and risk of fractures was 1.5 times higher in the CT genotype compared with the CC genotype, and 1.5 times higher in the CT genotype compared to the TT genotype. Thus, the risk allele for fractures is the $\mathrm{T}$ allele (Bathum et al. 2004). Similar results have been published by Villadsen et al. (2005), who demonstrated that the rare TT genotype of the C677T polymorphism was associated with an increased risk of osteoporotic fractures in women. Therefore, MTHFR seems to have a broader spectrum of body regulation, which includes bone quality.

Another gene associated with a risk of osteoporotic fractures is ALDH7A1. This gene is responsible for the detoxification of acetaldehyde, which is toxic to the skeleton. In Asian populations, an association between the rs13182402 SNP in this gene, and osteoporotic fractures, was detected by GWAS (Guo et al. 2010). The relationship has not yet been described in the Caucasian population.

The risk of fractures is due not only to bone mass or its microstructure, but is also due to the geometric parameters of the skeleton. Protein phospholipase c-like 1 (PLCL1) regulates the response of bone to mechanical load, especially in the hip. GWAS was used to find the relationship of the PLCL1 gene to the size of the hip in a population of women (Liu et al. 2008). However, the relationship between the geometric parameters of the skeleton and the PLCL1 gene could have an ethnic component. Additional genes related to the risk of fracture are shown in Table 3 (Mitchell and Streeten 2013).

Do candidate genes for BMD modulate osteotropic hormone expression?

Pilot association studies in a sample of 112 postmenopausal women found links between serum levels of androstenedione (a precursor of sex steroids) and the CTR gene (Zofkova et al. 2004) and/or the ER gene (Zofkova et al. 2002). In the same group of women, associations were found between parathyroid hormone levels and the VDR gene (Zofkova et al. 2003b, Laaksonen et al. 2009), as well as between FSH levels and LRP5 (Zofkova et al. 2007).
On the other hand, bone density also seems to be modulated by the gene that has been primarily identified as a regulator of the extraskeletal system. In our group of postmenopausal women we found that carriers of the risk E4 allele in the gene for apolipoprotein (APOE, determining lipid metabolism) had lower bone mineral density in the spine than the carriers of the E1, E2 and E3 alleles (Zajíčková et al. 2003).

Altogether, these observations allow us to postulate, that gene pleiotropism, which most probably developed during evolution, integrates calcium into whole body homeostasis. This hypothesis, however, needs to be strengthened by additional studies on large samples using GWAS analysis.

\section{Pharmacogenetics of osteoporosis}

The aim of pharmacogenetics is the individual choice of pharmaceuticals that can be reasonably expected to be the most effective treatment with the lowest risk of side effects. To date, the pharmacogenetics of antiresorptive agents (bisphosphonates and estrogen or SERMs) has been the focus of research.

Genes modulating the response of bone to bisphosphonates

Mevalonate is a target for the aminobisphosphonates (alendronate, ibandronate, risedronate, zoledronate), which block the synthesis of cholesterol by the enzyme farnesyl diphosphate synthase (FDPS). The consequence of this blockade is the accumulation of nonprenylated proteins, which inhibit osteoclast function and accelerate their demise. The FDPS gene has a predictive role in BMD values and bisphosphonate treatment efficacy (reviewed by Riancho and Hernández 2012). The rs 2297480 and rs 1126435 polymorphisms in the FDPS gene were associated with the response of bone to long-term bisphosphonate therapy, in postmenopausal Caucasian women. The carriers of the A allele had a better response on BMD and biochemical markers on alendronate or ibandronate treatments (Marini et al. 2008). Similarly, an association between the rs2297480 and rs1164359 polymorphisms in the FDPS gene, and response to treatment with alendronate or risedronate, has been shown in Spanish women. In the study, a $1 \%$ rise in BMD was observed in women with the AA genotype (the rs2297480 polymorphism), while the value of bone density in women carrying the CC genotype decreased by $1.6 \%$. Improved skeletal response to bisphosphonates was also observed in 
women carrying the $G$ allele in the rs1126435 polymorphism (Olmos et al. 2012). The risk allele (which may predict adverse effects of bisphosphonates on the skeleton) is the $G$ allele in the rs 17024608 polymorphism of the RBMS3 gene. The relationship of the OPG gene relative to bone response to alendronate has been found in postmenopausal Chinese women (reviewed by Riancho and Hernández 2012).

The Sp1 COL1A1 gene was also found associated with the response of bone mass to long-term bisphosphonate therapy. The etidronate-treated postmenopausal women with the SS genotype achieved a higher values of BMD compared to women with the Ss or ss genotypes (Qureshi et al. 2002).

Furthermore, positive relationships between the BMD response to risedronate and $\mathrm{V} 6677 \mathrm{M}$ (the rs4988321 polymorphism) and/or V1330V (the rs3736228 polymorphism) in the LRP5 gene, were observed in men (Kruk et al. 2009). Moreover, LRP5 is associated with the intestinal production of serotonin, which has a negative impact on bone metabolism. Therefore, the gene could be a potential predictor of the risk of osteoporosis in patients treated with selective serotonin reuptake inhibitors (SSRIs) (Wu et al. 2012).

Genes determining bone response to vitamin D administration

In a placebo-controlled study of girls undergoing long-term vitamin D supplementation, an association was found between BsmI and TaqI polymorphisms, and a percentage BMD increase in several parts of the skeleton (Arabi et al. 2009, reviewed by Riancho and Hernández 2012). Finally, associations between the response of bone to estrogen or SERM and PvuII polymorphisms in ER $\alpha$ and/or A266G in LRP5 genes has been demonstrated (Kobayashi et al. 2002, Heilberg et al. 2005, reviewed by Riancho and Hernández 2012). Nevertheless, these associations need to be confirmed by additional large studies, including those involving in men.

Pharmacogenetics may also predict the development of bisphosphonate adverse effects, such as osteonecrosis and/or fractures. An analysis of SPN in the VEGF and PPAR $\gamma$ genes, which regulate the transformation of precursor pluripotent cells into adipocytes or osteoblasts, is currently in progress. Attention is also being devoted to genes regulating the activity of the RANK / RANKL / OPG system. However, the results of this study have yet to be published (Olmos et al. 2012).

\section{Conclusions and future prospects}

Osteoporosis is a polygenic disease, wherein each bone phenotype (density, quality, metabolic rate) is the result of interaction among many weak genes. The "essential gene", responsible for the manifestation of osteoporosis has not yet been identified, despite utilizing the most advanced methods. Some random observations indicate the broader impact of candidate genes for porosis of the skeleton. We mentioned the relationships between the ER or CTR genes and levels of precursor sex steroids, and the association between LRP5 and circulating FSH the hormone, which activates bone resorption through interleukin $1-\beta$ and accelerates bone loss at high in vitro concentrations (Cannon et al. 2010). The regulatory effect of these genes on hormonal parameters needs to be further verified.

Genes are important in determining both peak bone mass and the rate of bone loss in later life. There is agreement that genetic factors are important, however, identifying the relevant genes have yielded inconsistent and conflicting results. Several genes are involved, some of which may be more important in particular ethnic groups than in others (Young 2002).

The genetics of osteoporosis has many pitfalls that prevent application of information to practical osteology. An unanimous consensus has not been reached in the relationship between certain candidate genes and bone phenotypes. This may be due to inconsistent methodological approaches (e.g. the selection of probands, extent, and homogeneity of investigated groups) or different allelic frequencies in the populations being compared. In addition, false positive results can be recorded in small groups, and are caused by linkage disequilibrium in candidate genes that are located in close proximity to another gene. A significant disturbing phenomenon is the effect of mutual interactions between genes (e.g. the interaction between ER and VDR) or between a gene and the environment (lifestyle, nutrition, physical activity). The effects of epigenetic factors should also be considered, as they modulate the relationships between the reference gene and phenotype by methylation of cytosine in DNA, and by histone modifications and small RNA molecules (miRNA). One of the limitations of association studies is the relatively low variability of bone phenotypes associated with the candidate genes (ranging between 7 and 10\%) (Marini and Brandi 2013, Riancho and Hernández 2012).

The GWAS method can partially overcome 
those pitfalls: it allows for the identification of a range of candidate genes and an assessment of the impact of their mutual interactions on the appropriate phenotype in a single measurement (genomics). So far, about 20 GWAS studies have recorded the association of genes with bone density, fractures, or skeletal geometry (Riancho and Hernández 2012). The analysis carried out on 47,000 probands found 82 loci related to bone density, and 6 loci related to fractures (Estrada et al. 2011). We can assume that, in the future, the GWAS method will allow for the identification of genes (in the DNA and miRNA) encoding the binding of drugs to target receptors, as well as transport mechanisms, pharmacokinetics and pharmacodynamics (Rukov and Shomron 2011).

Discordant findings in GWAS and metaanalyses have been observed. However, the metaanalyses of GWAS data should be better at uncovering novel loci in homogeneous populations, and thus better able to identify true osteoporosis genes than could be obtained through meta-analyses alone, particularly when the loss related to population heterogeneity is taken into consideration (Liu et al. 2013). From the point of further progress in genetics of osteoporosis, the polymorphic variations at multiple loci can be detected in the laboratory and subsequently analyzed mathematically with a computer using samples from very large numbers of affected individuals from multiplex families.

Despite all of the difficulties and numerous unanswered questions, the genetics (genomics) of osteoporosis remains a big challenge for further research in the field of pathogenesis, diagnosis and the personalized treatment of osteoporosis. Additionally, novel methods of the next generation, such as sequenations (both sides sequenation), multiple ligand probe analysis (MLPA), single strain conformation polymorphism analysis (SSCP), and fluorescent in situ hybridization (FISH) are expected to expedite progress in this research (Zheng 2013).

\section{Conflict of Interest}

There is no conflict of interest.

\section{Acknowledgements}

The work was supported by a Czech Ministry of Health project of the conceptual development of research organization 00023761 (Institute of Endocrinology, Prague).

\section{References}

ARABI A, ZAHED L, MAHFOUD Z, EL-ONSI L, NABULSI M, MAALOUF J, FULEIHAN GEL-H: Vitamin D receptor gene polymorphisms modulate the skeletal response to vitamin D supplementation in healthy girls. Bone 45: 1091-1097, 2009.

BATHUM L, VON BORNEMANN HJELMBORG J, CHRISTIANSEN L, MADSEN JS, SKYTTHE A, CHRISTENSEN K: Evidence for an association of methylene tetrahydrofolate reductase polymorphism C677T and an increased risk of fractures: results from a population-based Danish twin study. Osteoporosis Int 15: 659-664, 2004.

BRAGA V, MOTTES M, MIRANDOLA S, LISI V, MALERBA G, SARTORI L, BIANCHI G, GATTI D, ROSSINI M, BIANCHINI D, ADAMI S: Association of CTR and COLIA1 alleles with BMD values in peri- and postmenopausal women. Calcif Tissue Int 67: 361-366, 2000.

BROWN MA, NEWTON JL, WORDSWORTG BP: Genetics for Rheumatologists - The Molecular Genetic Basis of Rheumatic Disorders. Remedica Publishing, London, 2002.

CANNON JG, CORTEZ-COOPER M, MEADERS E, STALLINGS J, HADDOW S, KRAJ B, SLOAN G, MULLOY A: Follicle-stimulating hormone, interleukin-1, and bone density in adult women. Am J Physiol Regul Integr Comp Physiol 298: R790-R798, 2010.

CHAROPOULOS I, TROVAS G, STATHOPOULOU M, KYRIAZOPOULOS P, GALANOS A, DEDOUSSIS G, ANTONOGIANNAKIS E, LYRITIS GP: Lack of association between vitamin D and calcitonin receptor gene polymorphisms and forearm bone values of young Greek males. J Musculoskelet Neuronal Interact 8: 196203, 2008.

CZERNY B, KAMINSKI A, KURZAWSKI M, KOTRYCH D, SAFRANOW K, DZIEDZIEJKO V, BOHATYREWICZ A, PAWLIK A: The association of IL-1beta, IL-2 and IL-6 gene polymorphisms with bone mineral density and osteoporosis in postmenopausal women. Eur J Obstet Gynecol Reprod Biol 149: 82-85, 2010. 
ESTRADA K, EVANGELOU E, HSU Y-H, STYRKARSDOTTIR U, LIU CT, MOAYYERI A, KAPTOGE S ET AL.: Association analyses of 47,500 individuals identifies six fracture loci and 82 BMD loci clustering in biological pathways that regulate osteoblast and osteoclast activity. Bone $\mathbf{4 8}$ (Suppl 2): S69, 2011.

FARBER CR: Systems-level analysis of genome-wide association data. G3 (Bethesda) 3: 119-129, 2013.

GLASS DA, BIALEK P, AHN JD, STARBUCK M, PATEL MS, CLEVERS H, TAKETO MM, LONG F, MCMAHON AP, LANG RA, KARSENTY G: Canonical Wnt signaling in differentiated osteoblasts control osteoclast differentiation. Dev Cell 8: 751-764, 2005.

GUO Y, TAN LJ, LEI SF, YANG TL, CHEN XD, ZHANG F, CHEN Y, PAN F, YAN H, LIU X, TIAN Q, ZHANG ZX, ZHOU Q, QIU C, DONG SS, XU XH, GUO YF, ZHU XZ, LIU SL, WANG XL, LI X, LUO Y, ZHANG LS, LI M, WANG JT, WEN T, DREES B, HAMILTON J, PAPASIAN CJ, RECKER RR, SONG XP, CHENG J, DENG HW: Genome-wide association study identifies ALDH7A1 as a novel susceptibility gene for osteoporosis. PLoS Genet 6:e1000806, 2010.

HEILBERG IP, HERNANDEZ E, ALONZO E, VALERA R, FERREIRA LG, GOMES SA, BELLORIN-FONT E, WEISINGER JR: Estrogen receptor (ER) gene polymorphism may predict the bone mineral density response to raloxifene in postmenopausal women on chronic hemodialysis. Ren Fail 27: 155-161, 2005.

ICHIKAWA S, KOLLER DL, PEACOCK M, JOHNSON ML, LAI D, HUI SL, JOHNSTON CC, FOROUD TM, ECONS MJ: Polymorphisms in the estrogen receptor $\beta$ (ESR2) gene are associated with bone mineral density in Caucasian men and women. J Clin Endocrinol Metab 90: 5921-5927, 2005.

JIN H, VAN'T HOF RJ, ALBAGHA OM, RALSTON SH: Promoter and intron 1 polymorphisms of COL1A1 interact to regulate transcription and susceptibility to osteoporosis. Hum Mol Genet 18: 2729-2738, 2009.

KOBAYASHI N, FUJINO T, SHIROGANE T, FURUTA I, KOBAMATSU Y, YAEGASHI M, SAKURAGI N, FUJIMOTO S: Estrogen receptor alpha polymorphism as a genetic marker for bone loss, vertebral fractures and susceptibility to estrogen. Maturitas 41: 193-201, 2002.

KRUK M, RALSTON SH, ALBAGHA OM: LRP5 polymorphisms and response to risedronate treatment in osteoporotic men. Calcif Tissue Int 84: 171-179, 2009.

LAAKSONEN MM, OUTILA TA, KARKKAINEN MU, KEMI VE, RITA HJ, PEROLA M, VALSTA LM, LAMBERG-ALLARDT CJ: Association of vitamin D receptor, calcium-sensing receptor and parathyroid hormone gene polymorphisms with calcium homeostasis and peripheral bone density in adult Finns. J Nutrigenet Nutrigenomics 2: 55-56, 2009.

LI X, OMINSKY MS, WARMINGTON KS, MORONY S, GONG J, CAO J, GAO Y, SHALHOUB V, TIPTON B, HALDANKAR R, CHEN Q, WINTERS A, BOONE T, GENG Z, NIU QT, KE HZ, KOSTENUIK PJ, SIMONET WS, LACEY DL, PASZTY C: Sclerostin antibody treatment increases bone formation, bone mass, and bone strength in a rat model of postmenopausal osteoporosis. $J$ Bone Miner Res 24: 578-588, 2009.

LIU YJ, ZHANG L, PEI Y, PAPASIAN CJ, DENG HW: On genome-wide association studies and their meta-analyses: lessons learned from osteoporosis studies. J Clin Endocrinol Metab 98: E1278-E1282, 2013.

LIU YZ, WILSON SG, WANG L, LIU XG, GUO YF, LI J, YAN H, DELOUKAS P, SORANZO N, CHINAPPENHORSLEY U, CERVINO A, WILLIAMS FM, XIONG DH, ZHANG YP, JIN TB, LEVY S, PAPASIAN CJ, DREES BM, HAMILTON JJ, RECKER RR, SPECTOR TD, DENG HW: Identification of PLCL1 gene for hip bone size variation in females in a genome-wide association study. PLoS One 3: e3160, 2008.

MARINI F, BRANDI ML: The future of pharmacogenetics for osteoporosis. Pharmacogenomics 14: 641-653, 2013.

MARINI F, FALCHETTI A, SILVESTRI S., BAGGER Y, LUZI E, TANINI A, CHRISTIANSEN C, BRANDI ML: Modulatory effect of farnesyl pyrophosphate synthase (FDPS) rs2297480 polymorphism on the response to long-term amino-bisphosphonate treatment in postmenopausal osteoporosis. Curr Med Res Opin 24: 26092615,2008

MASI L, CIMAZ R, SIMONINI G, BINDI G, STAGI S, GOZZINI A, MALENTACCHI C, BRANDI ML, FALCINI F: Association of low bone mass with vitamin D receptor gene and calcitonin receptor gene polymorphisms in juvenile idiopathic arthritis. J Rheumatol 29: 2225-2231, 2002.

MENCEJ-BEDRAČ S, PREŽELJ J, MARC J: TNFRSF11B gene polymorphisms $1181 \mathrm{G} \geq \mathrm{C}$ and $245 \mathrm{~T} \geq \mathrm{G}$ as well as haplotype CT influence bone mineral density in postmenopausal women. Maturitas 69: 263-267, 2011. 
MITCHELL BD, STREETEN EA: Clinical impact of recent genetic discoveries in osteoporosis. Appl Clin Genet 6: 7585, 2013.

MORRISON NA, QI JC, TOKITA A, KELLY PJ, CROFTS L, NGUYEN TV, SAMBROOK PN, EISMAN JA: Prediction of bone density from vitamin D receptor alleles. Nature 367: 284-287, 1994.

OBERMAYER-PIETSCH B: Genetics of osteoporosis. Wien Med Wochenschr 156: 162-167, 2006.

OEI L, HSU YH, STYRKARSDOTTIR U, EUSSEN BH, DE KLEIN A, PETERS MJ, HALLDORSSON B, LIU CT, ALONSO N, KAPTOGE SK, THORLEIFSSON G, HALLMANS G, HOCKING LJ, HUSTED LB, JAMESON KA, KRUK M, LEWIS JR, PATEL MS, SCOLLEN S, SVENSSON O, TROMPET S, VAN SCHOOR NM, ZHU K, BUCKLEY BM, COOPER C, FORD I, GOLTZMAN D, GONZÁLEZMACIAS J. LANGDAHL BL, LESLIE WD, LIPS P, LORENC RS, OLMOS JM, PETTERSSON-KYMMER U, REID DM, RIANCHO JA, SLAGBOOM PE, GARCIA-IBARBIA C, INGVARSSON T, JOHANNSDOTTIR H, LUBEN R, MEDINA-GÓMEZ C, ARP P, NANDAKUMAR K, PALSSON ST, SIGURDSSON G, VAN MEURS JB, ZHOU Y, HOFMAN A, JUKEMA JW, POLS HA, PRINCE RL, CUPPLES LA, MARSHALL CR, PINTO D, SATO D, SCHERER SW, REEVE J, THORSTEINSDOTTIR U, KARASIK D, RICHARDS JB, STEFANSSON K, UITTERLINDEN AG, RALSTON SH, IOANNIDIS JP, KIEL DP, RIVADENEIRA F, ESTRADA K: A genome-wide copy number association study of osteoporotic fractures points to the 6p25.1 locus. J Med Genet 51: 122-131, 2014.

OLMOS JM, ZARRABEITIA MT, HERNÁNDEZ JL, SAŇUDO C, GONZÁLEZ-MACÍAS J, RIANCHO JA: Common allelic variants of the farnesyl diphosphate synthase gene influence the response of osteoporotic women to bisphosphonates. Pharmacogenomics J 12: 227-232, 2012.

ONGPHIPHADANAKUL B: Osteoporosis: the role of genetics and the environment. Forum Nutr 60: 158-167, 2007.

O'SULLIVAN ES, VAN DER KAMP S, KILBANE M, MCKENNA M: Osteogenesis imperfecta in adults: phenotypic characteristics and response to treatment in an Irish cohort. Ir J Med Sci 183: 225-230, 2014.

PRIMORAC D, ANTICEVIĆ D, BARISIĆ I, HUDETZ D, IVKOVIĆ A: Osteogenesis imperfecta - multi-systemic and life-long disease that affects whole family. Coll Antropol 38: 767-772, 2014.

QURESHI AM, HERD RJ, BLAKE GM, FOGELMAN I, RALSTON SH: COLIA1 Sp1 polymorphism predicts response of femoral neck bone density to cyclical etidronate therapy. Calcif Tissue Int 70: 158-163, 2002.

RALSTON SH, UITTERLINDEN AG, BRANDI ML, BALCELLS S, LANGDAHL BL, LIPS P, LORENC R, OBERMAYER-PIETSCH B, SCOLLEN S, BUSTAMANTE M, HUSTED LB, CAREY AH, DIEZ-PEREZ A, DUNNING AM, FALCHETTI A, KARCZMAREWICZ E, KRUK M, VAN LEEUWEN JP, VAN MEURS JB, MANGION J, MCGUIGAN FE, MELLIBOVSKY L, DEL MONTE F, POLS HA, REEVE J, REID DM, RENNER W, RIVADENEIRA F, VAN SCHOOR NM, SHERLOCK RE, IOANNIDIS JP; GENOMOS INVESTIGATORS: Large-scale evidence for the effect of COLIA1 Sp1 polymorphism on osteoporosis outcomes: the GENOMOS study. PLoS Med 3: e90, 2006.

RIANCHO JA, HERNÁNDEZ JL: Pharmacogenomics of osteoporosis: a pathway approach. Pharmacogenomics 13: 815-829, 2012.

RIANCHO JA, VALERO C, ZARRABEITIA MT, GARCIA-UNZUETA MT, AMADO JA, GONZALEZ-MARCIAS J: Genetic polymorphisms are associated with serum levels of sex hormone binding globulin in postmenopausal women. BMC Med Genet 9: 112, 2008.

RICHARDS JB, RIVADENEIRA F, INOUYE M, PASTINEN TM, SORANZO N, WILSON SG, ANDREW T, FALCHI M, GWILLIAM R, AHMADI KR, VALDES AM, ARP P, WHITTAKER P, VERLAAN DJ, JHAMAI M, KUMANDURI V, MOORHOUSE M, VAN MEURS JB, HOFMAN A, POLS HA, HART D, ZHAI G, KATO BS, MULLIN BH, ZHANG F, DELOUKAS P, UITTERLINDEN AG, SPECTOR TD: Bone mineral density, osteoporosis, and osteoporotic fractures: a genome-wide association study. Lancet 371: 1505$1512,2008$.

RIGGS BL, NGUYEN TV, MELTON LJ, MORRISON NA, O'FALLON WM, KELLY PJ, EGAN KS, SAMBROOK PN, MUHS JM, EISMAN JA: The contribution of vitamin D receptor gene alleles to the determination of bone mineral density in normal and osteoporotic women. J Bone Miner Res 10: 991-996, 1995.

RUKOV JL, SHOMRON N: MicroRNA pharmacogenomics: post-transcriptional regulation of drug response. Trends Mol Med 17: 412-422, 2011. 
SIMPSON ER: Role of aromatase in sex steroid action. J Mol Endocrinol 25: 1549-1556, 2000.

UELAND T, BOLLERSLEV J, WILSON SG, DICK IM, ISLAM FM, MULIN BH, DEVINE A, PRINCE RL: No associations between OPG gene polymorphisms or serum levels and measures of osteoporosis in elderly Australian women. Bone 40: 175-181, 2007.

UITTERLINDEN AG, BURGER H, HUANG Q, YUE F, MCGUIGAN FE, GRANT SF, HOFMAN A, VAN LEEUWEN JP, POLS HA, RALSTON SH: Relation of alleles of collagen type Ialpha1 gene to bone density and the risk of osteoporotic fractures in postmenopausal women. N Engl J Med 338: 1016-1021, 1998.

VALADARES ER, CARNEIRO TB, SANTOS PM, OLIVEIRA AC, ZABEL B: What is new in genetics and osteogenesis imperfecta classification? J Pediatr (Rio J) 90: 536-541, 2014.

VAN DIJK FS, SILLENCE DO: Osteogenesis imperfecta: clinical diagnosis, nomenclature and severity assessment. Am J Med Genet A 164A: 1470-1481, 2014.

VAN MEURS JB, TRIKALINOS TA, RALSTON SH, BALCELLS S, BRANDI ML, BRIXEN K, KIEL DP, LANGDAHL BL, LIPS P, LJUNGGREN O, LORENC R, OBERMAYER-PIETSCH B, OHLSSON C, PETTERSSON U, REID DM, ROUSSEAU F, SCOLLEN S, VAN HUL W, AGUEDA L, AKESSON K, BENEVOLENSKAYA LI, FERRARI SL, HALLMANS G, HOFMAN A, HUSTED LB, KRUK M, KAPTOGE S, KARASIK D, KARLSSON MK, LORENTZON M, MASI L, MCGUIGAN FE, MELLSTRÖM D, MOSEKILDE L, NOGUES X, POLS HA, REEVE J, RENNER W, RIVADENEIRA F, VAN SCHOOR NM, WEBER K, IOANNIDIS JP, UITTERLINDEN AG: Large scale analysis of association between LRP5 and LRP6 variants and osteoporosis. The GENOMOS study. JAMA 299: 1277-1290, 2008.

VILLADSEN MM, BÜNGER MH, CARSTENS M, STENKJAER L, LANGDAHL BL: Methylenetetrahydrofolate reductase (MTHFR) C677T polymorphism is associated with osteoporotic vertebral fractures, but is a week predictor of BMD. Osteoporos Int 16: 411-416, 2005.

WANG C, HE JW, QIN YJ, ZHANG H, HU WW, LIU YJ, ZHANG ZL: Osteoprotegerin gene polymorphism and therapeutic response to alendronate in postmenopausal women with osteoporosis. Zhonghua Yi Xue Za Zhi 89: 2958-2962, 2009.

WHYTE MP, REINUS WH, MUMM S: High-bone-mass disease and LRP5. N Engl J Med 350: 2096-2099, 2004.

WU Q, BENCAZ AF, HENTZ JG, CROWELL MD: Selective serotonin reuptake inhibitor treatment and risk of fractures: a meta-analysis of cohort and case-control studies. Ostetoporos Int 23: 365-375, 2012.

YOUNG ID: Genetics for Orthopedic Surgeons - The Molecular Genetic Basis of Orthopedic Disorders. Remedica Publishing, London, 2002.

ZAJICKOVA K, ZOFKOVA I, HILL M, HORINEK A, NOVAKOVA A: Apolipoprotein E 4 allele is associated with low bone density in postmenopausal women. J Endocrinol Invest 26: 312-315, 2003.

ZHENG HF: An example design of large-scale next-generation sequencing study for bone mineral density. IBMS BoneKEy 10: Art. Nr. 398, 2013.

ZOFKOVA I, ZAJICKOVA K, HILL M: The estrogen receptor alpha gene determines serum androstenedione levels in postmenopausal women. Steroids 67: 815-819, 2002.

ZOFKOVA I, ZAJÍČKOVA K, HILL M, KREPELOVA A: Does polymorphism C1377T of the calcitonin receptor gene determine bone mineral density in postmenopausal women? Exp Clin Endocrinol Diabetes 111: 447-479, 2003a.

ZOFKOVA I, ZAJICKOVA K, HILL M: Serum parathyroid hormone levels are associated with FokI polymorphism of the vitamin D receptor gene in untreated postmenopausal women. Eur J Intern Med 14: 232-236, $2003 \mathrm{~b}$.

ZOFKOVA I, ZAJICKOVA K, HILL M: Postmenopausal serum androstenedione levels are associated with the calcitonin receptor gene polymorphism T1377C. A pilot study. J Endocrinol Invest 27: 442-444, 2004.

ZOFKOVA I, HILL M, ZAJÍČKOVA K: Association of C/T polymorphism in the LRP5 gene with circulating follicle stimulating hormone in Caucasian postmenopausal women. Physiol Res 56: 735-739, 2007. 